UDC 332

\title{
THE ROLE OF SOCIAL CAPITAL IN DEVELOPING COMMUNITY-BASED TOURISM INSTITUTIONS IN BALI
}

\author{
Agustina Made Dian Putri, Susanti Putu Herny \\ University of Hindu Indonesia, Denpasar, Bali, Indonesia \\ *E-mail: dpagustina87@gmail.com
}

\begin{abstract}
The development of tourism plays an important role as a center for economic development and growth in creating a healthy and dynamic climate through the management of business and tourism activities in the regions. The purpose of this study is to determine the role of social capital in preserving community-based tourism institutions in Bali. This research uses qualitative research with a descriptive approach. The result of this research is that the role of institutions in supporting tourism will provide both material and non-material contributions to the local community, the social capital in the community can strengthen community-based tourism institutions and can strengthen tourism institutions in Badung Regency through the Tri Hita Karana approach. The advice that can be given is that community empowerment in community-based tourism development should be carried out jointly by the government, private sector, and the community.
\end{abstract}

\section{KEY WORDS}

Social capital, tourism institutions, Tri Hita Karana.

Tourism is considered as one of the industries that can provide fast economic growth in terms of employment opportunities, income, and standard of living and can activate other production sectors in a tourist receiving country (Sutrisno, 2013). The tourism sector is considered as a means to achieve sustainable development by providing very significant benefits in the economic, environmental, and socio-cultural fields as well as the widest possible opportunity for local communities to improve their welfare (Sharpley, 2002). According to Mostafa Kamal and Shah Alam Kabir Pramanik (2015), the tourism sector is an integrated sector that includes culture, scenic beauty, archaeological and historical sites, socio-politics, and infrastructure development.

The concept of sustainable development is adopted by the tourism sector and is further defined as tourism development carried out to meet the current needs of tourists and local communities by maintaining and developing opportunities for future development to meet all economic, social, and aesthetic needs, while still maintenance of cultural integrity, essential ecological processes, biological diversity, and life support systems (UN-WTO, 2004). The effort to find a link between tourism and sustainable development is stated by Sharpley (2009) who states that sustainable tourism development is a development that focuses on two things, on the one hand, sustainability as an economic activity, and the other side is a policy-oriented towards long-term goals and between generations.

The development of the tourism sector is one of the efforts to improve the community's economy both at the local and global levels. The tourism industry in Indonesia is experiencing rapid development. One of the tourism principles contained in Law no. 10 of 2009 concerning tourism is to empower local communities where the community has the right to play a role in the tourism development process and is obliged to maintain and preserve tourist attractions; as well as helping to create a safe, orderly, clean, polite attitude and preserving the environment of tourism destinations.

The professionalism of tourism destination management will determine the following three main points, namely: a) the advantages and attractiveness of these destinations for tourists; b) ecological, economic, social, and cultural benefits for the community and region; and c) competitiveness among international tourism destination markets (Damanik \& Teguh, 2012). Several important reasons were expressed by Damanik \& Teguh why the principles of 
sustainability need to be applied in the management of tourism destinations in Indonesia: first, the sharpness of destination competition at the global and national levels; secondly, the high variation and inequality in the development of tourism destinations in the country; and third, the low competitiveness of Indonesian tourism compared to neighboring countries.

This harmonious relationship is closely related to development practices to increase economic benefits that are in line with the protection of nature, socio-culture, and the environment so that the lives of local communities and destinations can be improved (Edgell, et al., 2008). The local community as one of the stakeholders is the main actor and key to the successful management and development of tourism destinations through their participation, which is an important feature of the community-based tourism development model (CBT = Community Based Tourism). Garrod (2003) who sees CBT as a form of participatory planning, its success will be determined by several things, including: (1) the existence of effective leadership; (2) local community empowerment; (3) there is a link between economic benefits and conservation; (4) involvement of local stakeholders in every stage of the project; and (5) local community participation in project monitoring and evaluation. Yaman \& Mohd (2004) add several key aspects to tourism development with the CBT approach, namely: first, there is government support; second, stakeholder participation; third, fair profit sharing; fourth, sustainable use of local resources; fifth, strengthening local institutions; and sixth, the linkages between regional and national levels. The participation of local communities in tourism development can be seen from two perspectives, namely participation in the decision-making process (decision-making process) and participation related to the perceived benefits of the tourism development in the region (Timothy, 1999). Apart from being involved in the decision-making process, the participating communities must share in the benefits and enjoy the results of development (Cohen \& Uphoff, 1980). Community participation is largely determined by various factors. Public participation can be increased by overcoming barriers to participation, while at the same time taking the steps necessary to promote the principles of sustainable participation (Theron, 2005). The development and development of tourism based on community participation will spur social and economic growth which in turn will affect people's lives, the level of community welfare, employment opportunities, and community income. The institution is considered the same as the player of the game, the rules of the game, or the outcome (equilibrium) of the game. Yustika (2008) defines that an institution can be viewed as a process and a goal. Yuliarmi (2011) argues that social capital has a very broad and complex dimension coverage.

Social capital is an ability that arises from the existence of trust (trust) in a community. One of the social capital needed to support the success and sustainability of natural tourism development is the existence of a visible social network that occurs between stakeholders (Lyon in Rachmawati, et al, 2011). Things that can influence the formation of social networks are the existence of good relations between the stakeholders involved (Weiler and Laing in Rachmawati, et al, 2011).

The Regional Government of Bali Province relies heavily on the tourism sector as a driver for increasing regional income which in turn improves the quality of life of the Balinese people in general. Erawan (2003: 2) states that the Bali tourism development paradigm should be adjusted to the sustainable tourism development paradigm, namely the tourism development paradigm that uses the following approaches: community participation (community-based approach), sustainable tourism development (sustainable tourism development), and community-based tourism).

In the context of equitable development results, Cook et al. (2003) present empirical evidence that government policies are decisive in the innovation development agenda to build tourist destination areas. Government policies also control the direction of sectoral developments that have an impact on the welfare of the community concerned, economic actors, and the business world as well as other public service centers (Herrera and Nieto, 2008). The role of the government will significantly contribute to the power base of business and the formation of social welfare (Wolff, 2002). Thus, the function of government policies in various countries plays a role, among others, encouraging the development of corporate innovation, providing financial assistance, regulations to protect businesses, and 
empowerment policies (Mustar and Laredo, 2002; Wolff, 2002). In developing communitybased tourist destinations, good synergy is needed from the government, local communities, and the private sector starting from planning, implementation, to evaluation. The government issued policies based on scientific studies and established local institutions to educate residents to be aware of the tourism potential that exists in their area. This local institution plays an important role in developing tourist destinations. How do they provide an understanding of the potential for tourism in the area in the hope that local people will be able to directly manage the tourism potential in their area? So that the positive impact of tourism can be felt directly by the local community.

\section{LITERATURE REVIEW}

Tourism is the activity of a person who travels to or lives in a place outside the environment, which is usually not more than one year continuously to get pleasure, do business, or other purposes, on the other hand. Taroepratjeka (1998) states that tourism activities are activities that bring people together with a situation outside their environment and can cause a sense of awe, feel comfortable, and can even pose a challenge to them. The state in question can take the form of a natural, cultural, or special condition, both as an object and as an attraction.

UNWTO defines sustainable tourism as tourism which fully takes into account the present and future economic, social, and environmental impacts, responding to the needs of visitors to industry (tourism), the environment, and the host community (ILO, 2012).

The concept of sustainable tourism, introduced by the World Commission on Environment and Development (WCAD) in the Brunland Report in 1987, states that: Sustainable development is a development that meets the needs of the present without compromising the ability of future generation to meet their own needs (Fagance, 2001). Likewise, the WTO puts forward development principles which include: first, ecological sustainability; second, social and cultural sustainability; and third, economic sustainability; both for present and future generations (Suwena, 2010).

Over time, the concept of sustainable development has been adopted into the concept of sustainable tourism development. Wall in Suwena (2010), emphasizes sustainable tourism development not only on ecology and economy but also on cultural sustainability because the culture is also an important resource in tourism development. Therefore, Suwena (2010) categorizes a tourism activity as sustainable if it meets the following requirements: 1) Ecologically sustainable, where tourism development does not have a negative effect on the local ecosystem; 2) Socially acceptable, which refers to the ability of residents to absorb tourism businesses (industry and tourists) without causing social conflict; 3) It is culturally acceptable, that is, local people can adapt to quite different tourist cultures (tourist culture); and 4) Economically profitable, namely the benefits of increasing the welfare of the community.

The noble objective of sustainable tourism development is actually that tourism development (must) be based on: first, the principle of environmental ecological sustainability where the tourism object is located; second, maintaining the socio-cultural continuity of the community. This is important considering that in addition to the carrying capacity of the natural environment, the socio-cultural sustainability of the community is the main pillar in tourism attraction; third, economic continuity is necessary for the community and region to obtain (obtain) a positive result from the development of tourism; and fourth, benefits for both present and future generations. The importance of the role of the local community in tourism development is because it is people who know more about the ins and outs of the environmental conditions in which they live, compared to other people outside their community (Arismayanti, 2010).

Dengnoy in Nugroho and Aliyah (2013) states that community-based tourism development is developed based on the principle of balance and harmony between the interests of various tourism development stakeholders including government, private, and community. Community-based tourism development aims to: 1) empower the community; 2) increasing 
the role and participation of the community in tourism development to obtain economic and socio-cultural benefits from tourism development; 3) provide equal opportunities to all members of society. Therefore, community-based tourism development requires coordination and cooperation as well as a balanced role between various elements of stakeholders including government, private sector, and society.

The approach that can be used to develop community-based tourism is participatory. This approach is used to encourage the formation of partnerships among the relevant stakeholders. In this case, the local community must be made aware of their potential so that they have a sense of belonging (a sense of belonging) to various natural and cultural resources as assets for tourism development. Furthermore, if tourism stakeholders are associated with community-based tourism (Natori, 2001: 6), then tourists are the capital that will be processed by the three stakeholder components (government, tourism entrepreneurs, and the community) whose results will be enjoyed by tourists.

Of course, tourism development cannot be separated from participation. The community is no longer placed as an object that only accepts what is decided from above (the government), but society at this time must also be involved as a subject in the framework of developing tourism (Manafe, 2003). Subadra (2006) states that the involvement of local communities in tourism development can be done by First, renting out their land to tourism operators to be developed as tourism objects and attractions and participating in monitoring the impacts caused in connection with the tourism development; Second, work as a permanent or part-time employee at the tour operator company; Third, providing services to tourism operators, such as food services, transportation, accommodation and tour guides (guiding); Fourth, forming a joint venture (joint venture) with the private sector, where the local community provides the location and services while the private sector handles product marketing and company management issues; Fifth, develop tourism independently by prioritizing community-based tourism development.

Mubyarto (2000) defines an institution as an organization or rules, both formal and informal, that regulate the behavior and actions of certain community members both in their daily routine activities and in their efforts to achieve certain goals. Some other experts interpret institutional norms as rules of regulations or organizations that facilitate organizations that facilitate coordination in the form of individual expectations that might be achieved by working together (Rintuh, 2005: 3). According to Soekanto in Sukmana (2005: 23), institutions have the function of (1) providing guidelines, how to behave and behave in facing problems in life; (2) maintaining the integrity of society, and (3) providing guidance to society for social control, or becoming a behavior monitoring system. North (1990) argues that institutions are a pattern of relationships and structures between members of society or organizations that are mutually binding, contained in a network or organization, which can determine the form of relationships between humans or between organizations determined by limiting and binding factors in the form of norms code of ethics formal and non-formal rules to work together to achieve the desired goals. Bobi (2002) in Utami (2011) contains an institutional group of people who work together with a specific division of tasks to achieve the desired goal. The objectives of group participants can be different, but within the organization, it becomes a unity. Institutions emphasize more on the rules and collective action to realize public or common interests. Phil. A in Utami (2011) suggests the official form of an institution, namely a line organization (line organization, military organization); line agencies and staff (line and staff organization); functional organization.

Tourism has been increasingly recognized as a trigger for economic growth and opportunities for expansion of employment in developing countries. Even in several developing countries in the African region, it is proven that the presence of tourism has contributed to reducing poverty (Steiner, 2006). However, the success of developing the tourism sector is more determined by the role of government policies that actively participate in building regulations for tourism development (Jeffries, 2001). Pangestiin Pakage, Noak (2013) states that efforts to develop the use of environmental services experience many obstacles. The main obstacles in developing the use of environmental services are the unavailability of comprehensive utilization plans, unfavorable statutory regulations, 
stakeholder understanding, and awareness of the essence of conservation and low environmental services and scarcity of data on the potential value of environmental service resources. The constraints related to the scarcity of sufficiently reliable data on the potential of environmental services generated by the forestry sector are caused by several factors, among others.

The concept of social capital is broadly debated and has a dual or ambiguous meaning. This means that social capital still has different connotations so this ambiguity is still being considered (Andreson and Jack, 2002). There is still a conflict between the concepts commonly used in sociology and politics on the one hand (Putnam, 1993, 1995, Fotes and Londolt, 1996), and economics on the other (for example; Dasgupta \& Serageldin, 2000). One of the means pursued to find a solution is to apply the rational economic model of action to the social interaction processes studied by sociologists. This approach was pioneered by Coleman (1998) and theoretically developed by Delia Giusta, (1999); Casson \& Delia Giusta, (2004), and empirically by Knack \& Keefer, (1997). Coleman (1998) defines that social capital is an aspect of social structure that facilitates the actions of individuals or perpetrators/companies in a social structure. Furthermore, it is said that social capital is not a single entity, but is a compound entity with two basic elements, namely; 1) social capital includes several aspects of the social structure, and 2) social capital facilitates certain actions of actors (actors) both as individuals and companies within that structure. In this case, it means; the same as other types of capital, social capital is also productive, which achieves individual or corporate goals will not be realized without the existence of this social capital.

Putnam (1993) defines that social capital as the appearance of social organizations, such as trust, reciprocity, and networking which can improve the efficiency of society by facilitating coordination and cooperation for mutual benefits. Fukuyama (1995) states that social capital is an ability that arises as a result of trust in a community. Fukuyama (1999) clearly states that it is not certain that the shared norms and values that are guided by these attitudes, behaviors, and actions automatically become social capital, but sometimes only as norms and values and values shared value generated by the mutual trust (trust). Hasbullah (2006), which calls it the main elements of social capital. Furthermore, it is said that the study of social capital lies in how the community's ability in a group entity to participate in building a network to achieve common goals. Such cooperation is characterized by a pattern of reciprocal interactions that are mutually beneficial and are built on trust that is supported by positive and strong social norms and values. Meanwhile, Ridell (1997) states that there are three parameters of social capital, namely: (1) networking, (2) trust, and (3) norms.

\section{METHODS OF RESEARCH}

This research uses qualitative. Qualitative research is research that intends to understand the phenomenon of what research subjects experience holistically and using descriptions in the form of words and language, in a special natural context and by utilizing various scientific methods (Moleong, 2007: 6). The type of research approach is descriptive. Descriptive research is research that seeks to address existing problem solutions based on data.

\section{RESULTS AND DISCUSSION}

Djogo, et al (2003) state that in general, the definition of an institution includes the concept of deep-rooted social behavior patterns and continues or repeats itself. Institutional contains two important aspects, namely; "Institutional aspects" and "organizational aspects". Institutional aspects include social behavior or behavior where the core of the study is about values, norms, customs, folkways, usage, beliefs, ideas, doctrines, desires, needs, orientation, and others. While the organizational aspect includes the social structure or structure, with the core of the study being the role aspect. Furthermore, structural aspects include roles, activities, relationships between roles, social integration, general structure, 
comparison of textual structures with factual structures, structures of authority or power, relationships between activities and goals to be achieved, aspects of solidarity, clique, profiles, and power patterns.

According to Inskeep (1991), in the context of tourism, institutions are an important component in supporting the success of tourism. Institutions play a role in regulating resources and distribution of benefits to increase tourism potential (Triambodo \& Damanik, 2015). The urgency of institutional existence in the tourism sector is that institutions can act as a forum as well as a driving force in facilitating and developing community participation in the tourism sector (Triambodo \& Damanik, 2015). In developing tourism village institutions, it is necessary to have proper initial planning in determining program or activity proposals, especially for the Tourism Awareness Group (POKDARWIS) to be able to increase community knowledge and skills through the program being implemented (Sastrayuda, 2010).

The process of developing community-based tourism cannot always be carried out without an empowerment process. Areas that develop as tourist destinations are generally remote because these areas have a lot of natural, cultural, and local flora and fauna attractions (Ashley, Boyd \& Goodwin, 2000). People who live in this area tend not to have enough knowledge or ability to make decisions about the development of their area and to participate in tourism development (Tosun, 2000). Therefore, empowerment programs so that people can get the maximum benefit from the presence of tourism is needed. Experience with new tourist destinations shows that the presence of non-governmental organizations (NGOs) has the potential to support this process (Ricardson, 2010).

Non-governmental organizations have the ability and a variety of experiences, expertise, and capacities in their fields which will be important in the implementation and assessment of the environment, being socially and economically responsible in sustainable development (UN / Agenda 21: 1992). Also, the contribution of non-governmental organizations (NGOs) to sustainable tourism development (UNCSD NGO: 1999) can take the form of lobbying or supplying tourism industry institutions so that they can develop tourism management plans that take into account several factors. Non-governmental organizations have also contributed to the formulation of guidelines regarding public awareness of the development and training objectives for local tour operators and agencies so that the impact of tourism on local communities can be measured. The goal of nongovernmental organizations is to support and strengthen local communities through job creation, education, and training (Mylanopoulos \& Moira, 2010).

Furthermore, non-governmental organizations are considered to be an important factor affecting the competitiveness of a sustainable tourism business because they can guarantee the trust of the wider community about the rational use of environmental resources. Nongovernmental organizations act as educators, suppliers of technical knowledge, and expertise (Mylanopoulus \& Moira, 2010).

In ecotourism management, it is necessary to strengthen local institutions continuously in encouraging independent businesses and creating fair partnerships. According to CIFOR (2004), community-based tourism development uses a collaborative approach between stakeholders, including the government, communities, tourism businesses, the emergence of communities in rural Costa Rica is at a disadvantage in terms of skills, experience, and knowledge about industrial tourism. need institutional support for information, capacity building, and networking opportunities related to community-based enterprises (Scheyvens, 2003 in Trejos \& Chiang, 2009). According to Juska and Koening's (2006) research, organizations such as WCS would be advised to support local capacity building and encourage representative participation and decision making. Ultimately, investing in human capital, not infrastructure, will better prepare for a future with or without ecotourism. Marfo (2008) describes the importance of institutional participation and sensitivity to open opportunities for community participation, as well as the flexibility to accommodate the dynamics between various factors that affect participation in the community development process.

Subadra (2006) states that Non-Governmental Organizations (Non-Governmental 
Organizations) play an important role in the development and management of tourism in both developed and developing countries. The participation and involvement of non-governmental organizations in various tourism activities, especially tourism, has increased the positive impacts of tourism development and increased motivation to conserve nature and culture. The results of community participation in several tourist destinations that have been obtained are as follows:

Reducing negative impacts and excessive intensity on unspoiled or unspoiled environments and habitats; Increase tourists' awareness of natural and cultural resources, both of which are inseparable parts of their daily lives; Generating or bringing in funds from donors who care about natural and cultural resources so that they can carry out nature and cultural conservation activities to support sustainable tourism development.

According to Subadra (2006), there are several roles that can be played by nongovernmental organizations in tourism development, such as a facilitator or liaison among tourism stakeholders, for example: between the tourism industry and local communities, between protected area managers and local communities, and between government and local communities. The ability of non-governmental organizations to mediate between interested parties (interest parties) further strengthens its position as an independent institution and is completely impartial to one of the interested parties or neutral (neutral party); As the initiator of community-based ecotourism development to broaden goals and get a greater conservation impact by optimizing the role and cooperation with other stakeholders. As a trainer and provider of relevant information resources related to tourism issues. As a cooperative partner of protected area managers to implement the objectives of tourism development such as; environmental education program and natural resource utilization program. To supervise the performance of the government, especially the department that handles protected areas to ensure that its programs are running properly.

Social capital is a condition that must be fulfilled in development. Various problems and irregularities that occur in various countries, the main factor is the underdevelopment of social capital in society. Weak social capital will reduce the spirit of cooperation, exacerbate poverty, increase unemployment, crime, and hinder any efforts to improve the welfare of the population (Inayah, 2012).

So far, social capital has been seen as having a role in the development of a society and being the key to success. The components of social capital, namely mutual trust, cooperation networks, and norms, are considered to have a positive relationship with regional economic growth, especially in economic interactions in both developing and developed countries (Vipriyanti, 2011). The important role of social capital in this development is, of course, no exception in tourism development. Even the recognition of the importance of social capital in tourism emerges from the idea of a new paradigm in tourism development, namely a quality, sustainable and sociable paradigm which requires social capital (Pitana, in Atmadja, 2010).

People who have high social capital tend to work together, feel safe to talk, and can overcome differences. According to Mawardi (2007) that the role of social capital can increase the ability of a community or group to work together to build a network to achieve common goals. The role of social capital can support mutually beneficial interactions built on trust that is based on norms and positive social values.

Networking is one of the aspects of social capital that functions in moving the organization towards the ultimate goal of production activities that are received as a benefit in togetherness. Although networking is an important component in mobilizing the potential for social capital, networking always requires two other aspects of social capital to mobilize social capital in production activities in society. 
Eurasia: Economics \& Business, 2(44), February 2021

DOI https://doi.org/10.18551/econeurasia.2021-02

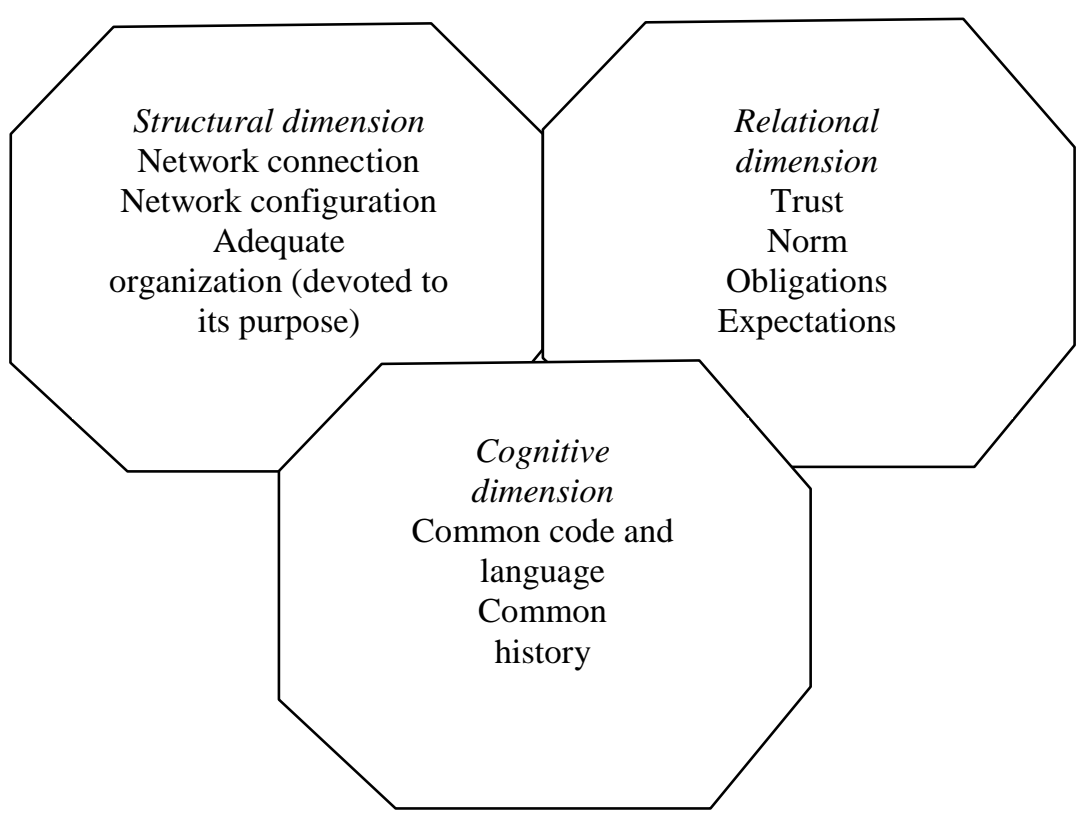

Figure 1 - Social Dimensions of Capital (Source: Coredeanu, 2010)

The role of networking in society and the potential for its development will be largely determined by the composition and demographic character as well as the socio-economic conditions of the community and the social structure of the community. The existence of social capital will be able to realize added value and benefits for society, if the three components can work together (see Figure 1), which includes structural dimensions, cognitive dimensions, and relational dimensions.

Based on the collaboration built on the above social capital components, it is hoped that a foundation can be obtained in realizing Community Based Tourism (CBT) which is managed and controlled by the local community (Hamzah \& Khalifah, 2010). Furthermore, based on Figure 2, to realize Sustainable Community Based Tourism Development (SCBTD), the process of community development stages through the empowerment of capacity building is mapped as a condition that the management of the community-based tourism industry can realize sustainable competitiveness which is determined by aspects of sustainability, low cost, and benefit society. (Taylor, 2006).

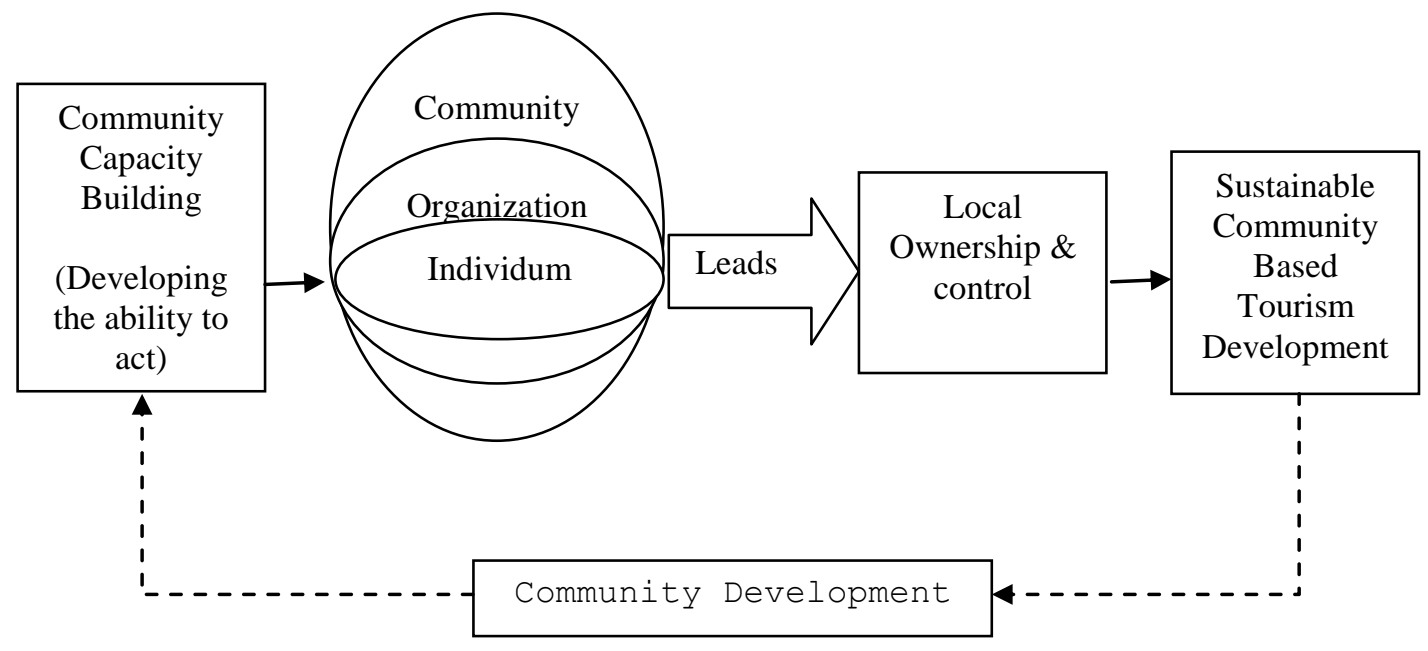

Figure 2 - Capacity Building Development Process (Source: Hamza and Khalifah, 2010) 
Based on Figure 2, it is hoped that community-based tourism can be realized through the development of community potential; related to the structure of the relationship between individuals, organizations, and communities that are driven as owners of the management of the tourism industry, which is expected to form a Sustainable Community Based Tourism Development (SCBTD).

The development of the tourism industry involves skilled resources in tourism services including four service components, namely accommodation, real estate, excursions and tours, and food and beverage. First, the linkage between tourism industry resources and business as reviewed by Clarige (2004), presents a social capital approach to community development in the context of structuring the tourism industry. In essence, the social capital approach is to carry out human resource development through potential networking including bonding, bridging, and linkage (Cavaye, 2000, Jamieson, 2011).

Second, social capital can carry out tracing through the concept of trust which is the basic foundation in the framework of an inter-community approach to togetherness, where all people who join the community get a share of the benefits of tourism shopping activities so that the presence of tourists can have an impact on the welfare of the community. Based on empowerment and economic impacts in the framework of better together, which can then be conditioned to achieve sustainable community-based tourism (SCBT), Noya and Clarence (2009).

Third, is a norm or tradition that can function as a cultural attraction and attraction for the benefit of entertainment tourism with certain uniqueness, without having a negative impact on local culture. The process of communication and linkages between local cultures and new cultures brought by tourists, do not damage local traditional values but should be able to develop dynamically in line with economic progress achieved by the presence of tourists as a trigger.

Likewise with the tourism sector, in terms of increasing tourism resources, good social capital is needed between the driving elements of the tourism sector. One of the social capitals needed to support the success and sustainability of natural tourism development is the existence of social networks that occur between the stakeholders involved (Lyon in Rachmawati, et al, 2011). Things that can influence the formation of social networks are the existence of good relations between the stakeholders involved (Weiler and Laing in Rachmawati, et al, 2011).

Soekanto in Rachmawati, et al (2011) states that good relations between stakeholders which are also commonly called social interactions are also a social process that occurs when there are social contact and communication between the parties involved. Social interaction is the main condition for the occurrence of social activities and is a dynamic relationship involving relationships between individuals, between groups, and between individuals and groups.

The people of Colo Village are required to participate in the development of tourism based on social capital in the community. Social capital based on reciprocity between norms and beliefs between communities or between groups of people in a network will optimize the potential that exists in society. The social capital that exists in society is usually packaged in the form of local institutions or groups of community organizations that form a network to achieve the same goal and are based on mutual trust and norms. These local institutions will contribute to increasing the social capital of the surrounding community (Syahriar \& Darwanto, 2015)

The formation of a strong network must be based on trust. According to Fukuyama (2007), trust is highly dependent on kinship, collectivity, ethnicity, and skills that develop in each individual in society. This belief is the expectation of order, honesty, and cooperative behavior that emerges from within a community which is based on the norms shared by its members.

According to Lawang, (2004) trust will facilitate the formation of cooperation. The stronger the trust in others, the stronger the cooperation that will exist between them. Social trust arises from relationships that are rooted in the norms of reciprocity and the network of citizenship linkages. Trust does not grow by itself, but through several processes that 
continuously strengthen trust.

Collaboration between community groups is a form of social capital in the form of networks that arise from the trust of community organizations in a community leader. This trust or trust will create a solid network together in terms of sharing, solving problems that occur in the field, as well as in the tourism development system. The role of leadership, namely a clear division of roles within an organization/community, shows that there is already a clear flow and structure to achieve tourism management goals. Where there is coordination between elements within the organization/group that can work together within and outside the organization/group which is a benchmark that tourism management is carried out well (Pamungkas, 2010; Pongponrat and Chantradoan, 2012; Trejos and Chiang, 2009). Social trust is a product of good social capital. The existence of good social capital is indicated by the existence of strong social institutions; social capital gives birth to a harmonious social life (Putnam, 1995).

The benefits that can be shared between the management and community members are a strong tie of the social network that is formed. A social network is a special thing in which it connects one point to another (Agusyanto, 2007: 13). The social network in a social group is something that is useful and brings good influence/reciprocity in the development of the group, for example through participation. Prusak in Baksh, et al. (2013) explains that social capital refers to a set of active relationships between humans. This aspect has been identified as a factor for building a community in a network and enabling cooperation among community members.

Community relations that can strengthen social capital such as community harmony in developing tourist villages can be seen from the enthusiasm of community members in participating in the activities held. Cooperation activities, cleaning the village, helping each other, and reminding each other in establishing communication will strengthen social networks that exist in a tourist village because all levels of society can participate.

Reciprocity is the tendency to exchange goodness between individuals in a group or between groups themselves. The exchange pattern occurs in a combination of the long and short term without expecting a return. The society and social groups that are formed having a strong reciprocity weight will give birth to a society that has a high level of social capital (Inayah, 2012). The development of social capital is supported by the weight of reciprocity which is manifested in reciprocity and giving, receiving, and helping each other which can lead to a process of interaction.

Norms are usually built, grown, and maintained to strengthen society itself. Social norms are created on purpose and people who initiate/participate in defending a norm feel that they are benefited by their obedience to the norm and at a loss for violating the norm. Violation of social norms can lead to conflicts and divisions in society, especially those in tourist village areas. Social norms are created on purpose. People who initiate/participate in defending a norm feel that they are benefited by their obedience to norms and suffer losses because they violate norms (Coleman, 2009: 333). Value is something that is considered true and important by members of society. For example, the value of harmony, achievement, hard work, competition, and others are examples of values that are very commonly recognized in society. The importance of instilling values in society is an important aspect of the formation of social capital in tourist village areas. Tourism development cannot be separated from the roles of the people or parties who have authority in this matter. Stakeholders, in this case, are people or institutions that have the authority or interest in tourism management and development. Lovelock (2003) in Pamungkas (2010) states that implementing the concept of tourism development requires good participation from stakeholders involved in tourism management in the form of collaboration and cooperation.

Often in the development and development of tourism, social interaction, and coordination in the form of collaboration between stakeholders who have authority have not been fully established. This happens because there is no package of cooperation and collaboration between them. This happens because there is frequent miscommunication between them so that the cooperation that will be carried out is not realized between them so that the cooperation that will be carried out is not realized. Minimal collaboration between 
stakeholders causes tourism development to be carried out independently and results in inefficiency in tourism development. Also, the role and participation of local communities in tourism development are usually less involved.

Institutional formation in tourism development requires a match at which stage or phase in the tourism destination cycle (life cycle destination). The exploration stage will differ in the number and quality of the institutions, as well as when it is at a higher stage such as involvement, the typology of the existence of the tourism institution will also be different. The progress of tourism is much influenced by professionalism and the existence of these institutions (tourism institutions). The more advanced the tourism institutions (quantity and quality), the more advanced it tends to be, the progress of tourism in an area.

Tourism in Bali in its current development efforts requires practical steps in building several tourism institutions. Based on the observations, the existence of tourism institutions in Bali is still relatively minimal and has not focused on its function and role. Based on the current conditions (existing), it turns out that the tourism institutions in the inventory are as follows Government (Tourism Culture Office); Private: PHRI, ASITA, HPI, IHGMA; Public: Pokdarwis

Based on the results of analysis and comparisons with several areas in Bali, Bali tourism needs to be built several tourism organizations or associations according to their fields and specifications. The first step that needs to be done is to realize institutional development facilitated by the local government. Several development efforts can be carried out, namely: First, the government needs to give more authority to the agency specified in the field of tourism in managing existing tourist attractions. If necessary, local governments need to make policies that focus on tourism development which are managed independently by the tourism office. In other words, the tourism office does not merge with other sectors or components. Second, the private sector is required to form tourism industry associations related to tour guide associations and marine tourism development. Third, to foster community innovation and creativity, it is necessary to be actively involved in tourism management.

Concretely, Balinese people need to be empowered through community-based development or tourism based on local communities. Development efforts that can be done by forming a management body in each DTW in Bali. The initial step can be started with the establishment of a management institution at the developing DTW-DTW, then followed by a potential (undeveloped) management organization at the DTW-DTW. Fourth, Collaboration (mix institutions): the weak power of tourism institutions in driving the progress of tourism development, many of which are caused by not being integrated (integrated) in building tourism. Tourism stakeholders tend to run independently, without exploiting the resources owned by other institutions. If cooperation and mutual benefits can be built through mutual trust, tourism will be developed more optimally.

The social capital owned by the Balinese people, such as community harmony in developing tourism, can be seen from the enthusiasm of the community in participating in the activities held. Networks are an aspect that must be fulfilled in building social capital because social capital is not built only by one individual, but lies in the growing tendency in a group to socialize as an important part of inherent values. Social capital will be strong depending on the existing capacity in community groups to build several associations and build networks. Social capital will be strong depending on the existing capacity in community groups to build several associations and build networks. The network that has been built by the community in Bali in developing their tourism is to collaborate with related parties to develop and promote the potential of their region.

Trust as an indicator of social capital becomes important so that each individual can develop together to achieve certain goals. If high capacity trust, society becomes well aware that the public interest is far more important than the personal interests of each individual. Trust between managers, residents, and parties working together in tourism development in Bali is very important because trust is the basis for a relationship. The trust that is carried out includes the trust of managers with community members. In this case, the trust shown is the desire to develop tourism and always act in an action that supports the development of DTW. 
The participation of the government and managers in instilling public trust is certainly not easy.

Social capital is used by someone to be able to live by socializing. Balinese people use Tri Hita Karana as social capital. The implementation of the Tri Hita Karana concept into three fields, namely the Parahyangan field (human relations with God), the pawongan field (human-human relations, and the palemah field (human-environmental relations) associated with the tourism industry (Dasi Astawa, 2007; Raka Dalem, 2007).

The concept of Tri Hita Karana for tourism managers and people today is to pay more attention to conservation efforts for the surrounding environment without forgetting God as the most important milestone in their business. This can be done with the existence of an environmentally friendly system, with the maintenance of the environment regularly, so that the natural beauty of the surroundings will be maintained, as well as reciprocity and exchange of opinions between managers and the surrounding community in the context of environment and security to create harmony between entrepreneurs and local communities. residents, as well as the construction and maintenance of holy place facilities that will have a spiritual impact on company members and also the surrounding community. So that there will arise a positive atmosphere, between nature managers, society, and also the spiritual level which is sometimes forgotten.

The three philosophies in Tri Hita Karana then become social capital for people in Bali. In maintaining these three relationships, it has also created values, norms, trust, networks, and information in social capital. In maintaining the relationship between humans and God, humans are expected to obey the rules, to distinguish between good and bad things to do, obligations and rights can be balanced. This is in the values and norms, besides that, the belief of the people in God arises. In the human-human relationship, there is a network and the delivery of information and trust in that relationship. Also, values and norms are formed to maintain relationships in society, so that a person does not act according to his wishes. This well-established relationship can then become capital between humans to add insights and networks that will later be useful in self-development and achieving goals.

Strengthening community-based tourism institutions related to efforts to optimize the role and participation of the community in the management of tourism resources both in the planning and monitoring processes. The findings of this study indicate that the problems and obstacles are (a) the absence of an autonomous and independent institution in tourism development in Bali so that local communities do not become involved in decision making, (b) local institutions do not play an optimal role in managing tourism resources, especially in efforts to conserve tourism resources, (c) lack of support from local governments in facilitating the functions and roles of community institutions at the local level, and (d) lack of coordination between stakeholders and sectors in the management of tourism resources. Therefore, strengthening local institutions needs to be done by (1) establishing autonomous and independent institutions as a forum to accommodate the aspirations of local communities to be involved in the management of tourism resources. (2) enhancing the role of local institutions in the management of tourism resources, especially in efforts to conserve resources, both in terms of protection, development, and utilization, and (3) increasing coordination and intensive integration among stakeholders. The program targets are (a) increased community participation in decision-making, improved institutional performance and effectiveness, and (b) increased coordination between stakeholders. Efforts to strengthen the capacity of local communities need to be supported by the commitment of the government and investors by providing wider space for the community to participate in contributing to the management of tourism resources. Support can be made through policy structural adjustments that are community-oriented.

\section{CONCLUSION AND SUGGESTIONS}

As stated in the description in the previous discussion, several conclusions can be drawn, namely the role of institutions in the form of groups, organizations in supporting tourism will provide both material and non-material contributions to the local community by 
creating social capital and one of the first steps for interaction between individuals one with another because the process of forming groups will fulfill the needs of the group which will motivate local people to take an active role in tourism development in their area.

The social capital contained in the community can strengthen community-based tourism institutions. Strong norms, trust, and networks, which are indicators of social capital, can strengthen relationships that exist between the community, government, and private parties. The community gives confidence to all circles as well as to the government to carry out their duties administratively which reflects the high level of social capital. The existence of moral norms and sanctions becomes a control for the community in acting so that it can ward off the bad effects of tourism. Social capital contained in the community can strengthen tourism institutions in Badung Regency. The imposition of moral sanctions which are part of a wig-awig becomes a control for society in acting. Tri Hita Karana is another form of social capital for people in Bali. Armed with this philosophy, society maintains a good relationship between man and God, man and man, and man and nature. So that values, norms, beliefs, networks, and information can run well in society.

Several suggestions that can be conveyed about the discussions that have been conveyed are the harmonious relations that have been established between the community and the community, the community, and the government, and the community and entrepreneurs that have been established can be used as capital to obtain broad information. Upholding honesty, strengthening networks with other parties so that in the long term it is expected to be able to increase community independence in realizing community-based tourism. Community empowerment in community-based tourism development should be carried out jointly by the government, private sector, and the community. If the local government, the private sector, and the community have collaborated, then the role of the government agencies is awaited by the community so that later tourism development can be of quality and sustainable. Further studies are needed to be related to the role of social capital in community-based tourism development, as well as impact analysis on tourism for the welfare of residents.

\section{REFERENCES}

1. Abdilah, F. dan S. M. Leksmono. 2001. Pengembangan Pariwisata Berkelanjutan. Jurnal Ilmu Pariwisata. Vol. 6, No. 1, Juli 2001.

2. Ancok, Jamaludin. 2003. Modal Sosial dan Kualitas Masyarakat, PDF, 23/02/2018.

3. Andereck, K.L.1995. Environmental consequences of tourism: a review of recent research. InMcCool, S.F. and Watson, A.E (eds) LinkingTourism, The Environment and Sustainability, General Technical Report No. INT-GTR-323, IntermountainResearch Station,Ogton, Utah, pp. 77-81

4. Andereck, K. L. dan Nyaupane, G. P. 2011. Exploring the nature of tourism and quality of life perceptions among residents. Journal of Travel Research, Vol. 50 No. 3, pp. 248260.

5. Anderson, A.R. and S.L. Jack, 2002, The Articulation of Social Capital in Entrepreneurial Networks: a glue or lubricant?, Entrepreneurialship and Regional Development, 14, 193-210.

6. Aref, F. 2011. Sense of Community and Participatiom for Tourism Development. Life Science Journal, 8(1), pp. 20-25.

7. 2011. The Effects of Tourism and Quality of Life: A Case Study of Shiraz, Iran. Life Science Journal, 8(2), pp. 216-24.

8. Arida, Nyoman Sukma. 2010. Strategi Alternatif Untuk Keberlanjutan Pariwisata Bali; dalam Pariwisata Berkelanjutan Dalam Pusaran Krisis Global. Udayana University Press: Denpasar.

9. Arismayanti, Ni Ketut. 2010. Arah Pembangunan dan Pengembangan Pariwisata Berkelanjutan di Bali. Udayana University Press: Denpasar.

10. Arnstein, S.R. 1969. A Ladder of Citizen Participation. Journal of the American Planning Association, 35(4), pp.216-24. 
11. Ashley, Carlotte Boyd \& Goodwin, Harod. 2000. Pro Poor Tourism: Putting Poverty at the Heart of the Tourism Agenda. ODI

12. Backman, K.F., Backman, S.J.U., Uysal, M. \& Sunshine, K.M. 1995. Event tourism and examination of motivations and activities. Festival Management and Events Tourism, Vol. 3, pp. 15-24.

13. Badrudin, Rudy. 2012. Ekonomika Ekonomi Daerah. Edisi Pertama. UPP STIM YKPN: Yogyakarta.

14. Badrudin, Rudy. 2012. Ekonomika Ekonomi Daerah. Edisi Pertama. Yogyakarta: UPP STIM YKPN.

15. Bourdieu, P., 1986. The Forms of Capital. In J. Richardson, ed. Handbook of Theory and Research for the Sociology of Education. Westport: Green-wood Press.

16. BPS Provinsi Bali., 2013. Bali Dalam Angka 2012. Denpasar.

17. Cameron, A.M., Memon, A., Simmons, D.G., Fairweather, J.R., 2001. Evolving Role of Local Goverment in Promoting Sustainable Tourism Development on the West Coast. Lincoln, New Zealand: Tourism Recreation Research and Education Centre (TTREC) Lincoln University.

18. Campbell, P. E.; Converse; Rodgers, W. L. 1976. The quality of American life. New York: Russell Sage Foundation.

19. Casson, Robert B \& Hofer, Charles W. 2006. Measuring Organizational Performance Matrics for Entrepreneurship and Strategic management Research, Published by Edward Elgar Publishing Limited, Glensanda House, United Kindom.

20. Cavaye, J. 2011. The Role of Government in Community Capacity Building. Journal of Hospitality \& Tourism, Vol. 5, Issue.

21. CIFOR. 2004. Pembangunan Pariwisata Berbasis Masyarakat. CIFOR. Bogor.

22. Cohen, J.M. \& Uphoff, N.T., 1980. Participation's place in rural development: Seeking clarity through specificity. World Development, Elsevier, 8(3), pp.213-35.

23. Cohen, D \& Prusak, L. 2001. In Good Company: How Social Capital Makes Organization Work. London: Harvard Busines press.

24. Coleman, J.S., 1988. Social capital in the creation of human capital. American Journal of Sociology, 94, pp.95-102.

25. 1990. Foundation of Social Theory, Cambridge, MA: Harvard University press.

26. Conyers, D. 1991. Perencanaan Sosial di Dunia ketiga. Yogyakarta: UGM Press.

27. Coredeanu, D. 2012, Empowerment of communities for sustainable tourism development: Case of Croatia. Email: lipe@efst.hr. Business and Management Review Vol. 25. http://www.businessjournalz.org/bmr.

28. Cox Eva. 1995. A Truly Civil Society. Sydney: ABC Bokks.

29. Crotts, J. C. dan Holland, S. M. 1993. Objective indicators of the impact of rural tourism development in the state of Florida. Journal of Sustainable Tourism, Vol. 1 No. 2, pp. 112-120.

30. Damanik, J., \& Teguh, F. 2012. Manajemen Destinasi Pariwisata: Sebuah Pengantar Ringkas. Kepel Press. Yogyakarta.

31. Darma P., \& Pitana, I G. 2010. Pariwisata Pro-Rakyat: Meretas Jalan Mengentaskan Kemiskinan di Indonesia. Jakarta: Kementrian Kebudayaan dan Pariwisata.

32. Dasgupta, P. and I. Sarageldin. 2000. Social Capital: A Multi-faceted Perspective, Washington, DC: The World Bank.

33. Dasi Astawa, 2007. "Tri Hita Karana sebagai Landasan Dasar dalam Pembangunan Industri di Bali”, dalam majalah Dharmasmerthi, Vol V No. 9, April 2007.

34. De Lacy, T., Battig, B., Moore, S., Noakes, S., 2002. Public - Private Partnerships for Sustainable Tourism: Delivering a Sustainability Strategy for Tourism Destinations. Gold Coast: CRC for Sustainable Tourism.

35. Delia Giusta, Marina. 1999. A Model of Social Capital and Access to Productive Resource, Journal of International Development, 11, 921-34.

36. Denhardt, J.V. \& Denhardt, R.B. 2003. The New Public Service: Serving, not Steering. M.E. Sharpe. New York \& London.

37. Dharmayudha, I Made Suasthawa dan I Wayan Koti Cantika. 1991. Filsafat Adat Bali. 
Upada Sastra: Denpasar.

38. Djogo, T., Sunaryo, S. D., \& Sirait, M. (2003). Kelembagaan dan kebijakan dalam pengembangan agroforestri Bahan ajaran agroforestri 8. Bogor: World Agroforestry Centre (ICRAF) Southest Asia.

39. Eadington, W.R. and V. Smith. 1992. Tourism Alternative: Potential and Problem in the Tourism Development. Philadelphia.

40. Edgell, D. L., Allen, M. D., Smith, G., \& Swanson, J. R. 2008. Tourism Policy and Planning: Yesterday, Today and Tomorrow. Great Britain: Elsevier Inc.

41. Edgell, D. L. 2006. Managing Sustainable Tourism: A Legacy for the Future. Binghamton, NY: The Haworth Hospitality Press.

42. Erawan, I N. 2003. Paradigma Baru Pengembangan Pariwisata Bali. Denpasar: Makalah

43. European Communities, 2003. A Manual for Evaluating the Quality Performance of Tourist Destinations and Services. Enterprise DG Publication, Luxembourg.

44. Eshliki, S. A., dan Kaboudi, M. 2012. Community perception of tourism impacts and their perception in tourism planning: A case study of Ramsar, Iran. Procedia-Social and Behavioral Sciences, 36, 333-341. http://dx.doi.org/10.1016/j.sbspro.2012.03.037

45. Fagance, Michael. 2001. Integrated Planning for Sustainable Tourism Development, dalam Abdilah Fitra dan Leksmono, S. Maharani. 2001. Pnegembangan Kepariwisataan Berkelanjutan. Jurnal IImu Pariwisata. Volume 6 No.1, Juli 2011.

46. Farrell,Bryan H. dan Dean Runyan.1991. Ecology And Tourism.Annals of Tourism Research, Vol. 18 No. 1,pp 26-40

47. Fauzi, A. 2004. Ekonomi Sumber Daya Alam dan Lingkungan, Teori dan Aplikasi. Gramedia Pustaka Utama: Jakarta.

48. Finzel, Hans. 2002. Sepuluh Besar Kesalahan yang Dibuat Pemimpin. Interaksara: Batam.

49. Fukuyama, F. 1995. Trust, The Social Virtues and the Creation of Prosperity, A Devision of Simon \& Schuster New York, Free Press Paperbacks.

50. 1995. Trust: Kebajikan Sosial dan Penciptaan Kemakmuran, Yogyakarta: Penerbit Qalam.

51. 1999. The end of History and The Last Man: Kemenangan Kapitalisme dn Demokrasi Liberal, Yogyakarta, Penerbit Qalam.

52. Garrod, B., 2003. Local Participation in the Planning and Management of Ecotourism: A Revised Model Approach. Journal of Ecotourism, 2(1), pp.33-53.

53. Godfrey, K., dan Clarke, J. 2000. The tourism development handbook: a practical approach to planning and marketing. London: Continuum.

54. Gunn, C. A. 1994. Tourism Planning (3rd ed.). New York: Taylor and Francis.

55. Gursoy dan D.G. Rutherford. 2004 Host attitudes toward tourism: An improved structural model,Annals of tourism Research, Vol. 31 No. 3, pp. 495-516.

56. Hamijoyo, S. 2007. Komunikasi Partisipatoris. Bandung: Humaniora.

57. Hamzah, A., khalifah, Z. 2009. Handbook on Community Based Tourism: How to Develop and Sustain CBT. In A. church \& T. Coles (Eds.), Tourism, power and space. Abingdon: Routledge.

58. Hasbullah, Jousairi. 2006. Social Capital (Menuju Keunggulan Budaya Manusia Indonesia, Jakarta, MR United Press.

59. Herrera, L. dan M. Nieto. 2008. The national innovation policy effect according to firm location, Technovation, Vol. 28 No. 8, pp. 540-550.

60. Holil S.1980. Partisipasi Sosial dalam Usaha Kesejahteraan Sosial. STKS. Bandung.

61. ILO. 2012. Rencana Strategis Pariwisata Berkelanjutan dan Green Jobs Untuk Indonesia.

62. Inayah, 2012, Peranan Modal Sosial dalam Pembangunan, Ragam Jurnal Pembangunan Humaniora, Vol 12. No 1. April 2012.

63. Inskeep, E. (1991). Tourism planning: an integrated and sustainable development approach: Van Nostrand Reinhold.

64. Isbandi, A.R. 2007. Intervensi Komunitas Pengembangan Masyarakat sebagai Upaya 
Pemberdayaan Masyarakat. Raja Grafindo Persada. Jakarta.

65. Jeffries, D.J. dan Butterworth Heinemann. 2001. Governments and tourism. InternationalJournal of Tourism Research,Vol. 4, Issue 6, pp. 487-488.

66. Jurowski, C.; Uysal, M.; Williams, D. R. 1997. A theoretical analysis of host reactions to tourism. Journal of Travel Research, Vol. 36 No. 2, pp. 3-11.

67. Knack, S and P. Keefer. 1997. Does Social Capital Have an Economic pay-off? A Cross-Country Investigation, Quaterly Journal of Economic, 112 (4), 1251-88.

68. Korten, D.C. \& Alfonso, F.B., 1983. Bureaucracy and the poor: closing the gap. West Hartford, Conn.: Kumarian Press.

69. Kuncoro, Mudrajat. 2004. Otonomi Daerah dan Pembangunan Daerah. Jakarta: Erlangga

70. Lansing, J.S., 1991. Priests and Programmers: Technologies of Power in the Engineered Landscape of Bali. Princeton University Press, Princeton, NJ.

71. Leiper, Neil. 1995.Tourism Management. Melbourne: RMIT Publishing (A 3rd edition of this book was published in 2004 by Pearson Education).

72. Leksakundilok, A. 2004. 1864872225 Ecotourism and Community-based Ecotourism in The Mekong Region. Working Paper \# 10. Sidney: University of Sidney.

73. Leksono, S. 2009. Runtuhnya Modal Sosial, Pasar Tradisional, Perspektif Emik Kualitatif, CV Citra Malang, Malang

74. Madiun, N. 2008. Partisipasi Masyarakat Lokal dalam Pengembangan Kawasan Pariwisata Nusa Dua (Perspektif Kajian Budaya). Disertasi. Program Pascasarjana Universitas Udayana. Denpasar. Tidak diterbitkan.

75. Manafe, Adi Hendrik. 2003. Wisatawan dan Penerimaan Masyarakat Lokal Nemberala. Tesis. Program Pascasarjana UKSW Salatiga: Salatiga.

76. Mantra, Ida Bagus. 1991. Indonesia Tourism Bali Experences, A Paper Presented at the 40th Annual PATA Conference in Bali.

77. Markandya, A., Taylor, T. \& Pedroso, S., 2003. Tourism and Sustainable Development: Lessons from Recent World Bank Experience. Research Report. Washington, D.C.: The World Bank IBRD.

78. McKean, Philip F. 1989. Towards a Theoretical Analysis of Tourism: Economic Dualism and Cultural Involution in Bali.

79. 1973. Cultural involution: tourists, Balinese and the process of modernization in an anthropological perspective. Unpublished Thesis, Brown University.

80. 1989. Toward a Theoretical Analysis of Tourism: Economic Dualism and Cultural Involution in Bali' pp. 119-36 in Valene Smith (ed) Hosts and Guests: The Anthropology of Tourism. Philadelphia, PA: University of Pennsylvania Press [orig. pub. 1977.

81. Meniarta, I Ketut., Mas'udi, Wawan., Dwipayana, A.A.G.N. Ari. 2009. Dinamika Sistem Kesejahteraan dan Modal Sosial di Masyarakat Banjar Pakraman-Bali. Jurnal IImu Sosial dan Ilmu Politik Volume: 13, Nomor 2, November 2009. pp. 231-248.

82. Morgan, J.Q., 2009. The Role of Local Goverment in Economic Development: Survey Findings from North Carolina. Research. Chapel Hill: School of Goverment University of North Caroline.

83. Moeljarto, T. 1987. Politik Pembangunan: Sebuah Analisis Konsep, Arah dan Strategi. Tiara Wacana, Yogyakarta. Edisi: Cetakan Pertama.

84. Murbyarto. 2000. Membangun Sistem Ekonomi. BPFE, Yogyakarta.

85. Murphy, P.E., 1985. Tourism: A Community Approach. London: Methuen \& Co. Ltd

86. Murtiyanto, N. 2011. Partisipasi Masyarakat (Teori Ringkas). Posted on October 12, 2011. http://bagasaskara.wordpress.com.

87. Mylanopoulos, D \& , Moira, P. 2010. The NGO's Contribution to Sustainable Tourism Development, the Case of Greece. International Society of Travel and Tourism Educators.

88. Naipinit, A. \& Maneenetr, T. 2010. Community Participation In Tourism Management In Busai Village Homestay, Wangnamkheo District, Nakhon Ratchasima Province, Thailand. The International Business \& Economics Research Journal, 9 (1): 103-109.

89. Ningrum, Indriani Rahma. 2014. Analisis Peran Modal Sosial Terhadap Pemberdayaan 
Masyarakat dalam Melestarikan Kebudayaan dan Pengembangan Sektor Pariwisata. Malang

90. North, Douglas. C. 1990. Institution; Institutional Change and Economic Performance, Cambridge, Press Syndicate of the University, Cambridge.

91. Onix, J. 1996. "The Measure of Social capital" paper presemted to Australian and New Zealand Third Sector Research Confrerence on Social Cehesion, Justice and Citizenship: The Role of Voluntary Sector, Victiria University, Wellington.

92. Pamungkas, G. 2010. Ekowisata Belum Milik Bersama: Kapasitas Stakeholder Dalam Pengelolaan Ekowisata (Studi Kasus: Taman Nasional Gunung Gede Pangrangno). Jurnal Perencanaan Wilayah dan Kota Vol. 24 No 1.

93. Penrose, Edith T. 1959. The Theory of the Growth of thr Firm, Oxford: Blackwell.

94. Permanasari, I K. 2011. Pemberdayaan Masyarakat melalui Desa Wisata dalam Usaha Peningkatan Kesejahteraan. Thesis, Magister Perencana-an dan Kebijakan Publik. Pascasarjana, FE, Universitas Indonesia, Jakarta. Tidak diterbitkan.

95. Picard, M. 1990. Cultural tourism in Bali: cultural performances as tourist attraction, Indonesia, Vol. 49, pp. 37-74.

96. 1993. Cultural tourism in Bali: National Integration and Regional Differentiation. In Michael Hitchcock, Victor T. King, and Michael J.G. Parnwell (eds) Tourism in SouthEast Asia. New York: Routledge. 71-98.

97. 1996. Bali: Cultural torism and touristic culture, Singapore: Archipelago Press.

98. 1996b. Kebalian orang Bali: tourism and the uses of "Balines culture" in New Order Indonesia, RIMA, Vol. 24, pp. 1-37

99. 1997. Cultural tourism, nation-building and regional culture: the making of a Balinese identity' in Picard, M and Wood, R.E. (eds), Tourism, Ethnicity and the State in Asian and Pasific Societies, Honolulu: University of Hawai'l Press.

100. 1999. The discourse of Kebalian: transtructultural constructions of Balinese identity', in Rubinstein, R. and Connor, L. (eds), Staying Local in the Global village: Bali in the twentieth century, Honolulu: University o Hawai'l Press

101. Pitana, I Gde. 1994. Mosaik Masyarakat dan Kebudayaan Bali dalam Dinamika Masyarakat dan Kebudayaan Bali. Penerbit Bali Post: Denpasar.

102. Pongpongrat, K dan N.J. Chantradoan. 2012. Mechanism Of Social Capital In Community Tourism Participatory Planning In Samui Island, Thailand. Taourismo: An International Multidiciplinary Jaournal Of Tourism Vol. 7 No. 1.

103. Pretty, Jules N.1995 .Participatory Learning and Action; A Trainer's Guide. 267pp, ISBN:189825002, HED

104. Prentice, Richard. 1993. Tourism and heritage attractions. National Library of Australia. London; New York: Routledge.

105. Putnam, R.D., 1993. The Prosperous Community - Social Capital and Public Life American Prospect, 13, pp.35-42.

106. 1995. Bowling Alone: America's Declining Social Capital. Journal of Democracy, 6(1), pp.65-78.

107. Raka Dalem, A A Gede. "Filosofi Tri Hita Karana dan Implementasinya dalam Industri Pariwisata" dalam Raka Dalem, dkk. (editor), 2007. Kearifan Lokal Dalam Pengelolaan Lingkungan Hidup, UPT Penerbit Universitas Udayana bekerjasama dengan Pusat Penelitian Lingkungan Hidup, Denpasar.

108. Ramseook-Munhurrun, Prabha dan Perunjodi Naidoo. 2011. Customers' Perspectives of Service Quality in Internet Banking. Publishing models and article dates explained,Vol. 32, Issue 4,pp. 247-264

109. Richards, G. 1987. Cultural Tourism in Europe. Wallingford: CAB International.

110. 2007. Cultural Tourism: Global and Local Perspectives. New York: The Haworth Hospitality Press

111. Richards, J. C.2001. Curriculum Development in Language Education. Cambridge: Cambridge University Press.

112. Richardson, Robert B. 2010. The Contribution of Tourism to Economic Growth and Food Security. USAID-Mali. 
113. Ritzer, George Goodman J. Gouglas. 2008. Teori Sosiologi. Penerbit Kreasi Wacana: Yogyakarta.

114. Sastrayuda, G. S. 2010. Konsep Pengembangan Kawasan Desa Wisata. Bandung: Universitas Pendidikan Indonesia.

115. Sastrayuda, Gumelar S. 2010. Hand Out Mata Kuliah Concept Resort And Leisure, Strategi pengembangan dan pengelolaan resort and leisure. http://file.upi.edu/Direktori/FPIPS/LAINNYA/GUMELAR_S/HAND_OUT_MATKUL_KON SEP_RESORT_AND_LEISURE/PENGEMBANGAN_KAWAS AN̄_DESA_WISATA.pdf. Diakses Tanggăl 2 Māet 2018.

116. Siagian, S. P. 1985. Analisis Serta Perumusan Kebijakan dan Strategi Organisasi. PT. Gunung Agung, Jakarta.

117. Setyadi, Yulianto Bambang. 1999. Pariwisata dan Pergeseran Pola Menetap Keluarga pada Masyarakat Bali. Laporan Penelitian. Fakultas Keguruan dan IImu Pendidikan Universitas Muhammadiyah: Surakarta.

118. 2000. Persepsi dan Partisipasi dalam Mendukung Usaha Pariwisata Berdasarkan Lingkungan Tradisi pada Masyarakat Bali. Jurnal Penelitian Humaniora. Vol 1 No 1 Pebruari 2000. Lembaga Penelitian Universitas Muhammadiyah: Surakarta.

119. Sharpley, R. 2002. Tourism and Development: Concepts and Issues. Multilingual Matters Limited.

120. 2009. Tourism Development and the Environment: Beyond Sustainability? New York: Earthscan.

121. Soetrisno, L. 1995. Menuju Masyarakat Partisipatif. Kanisius. Yogyakarta. Edisi: Cetakan Pertama.

122. Spinllane, J. James. 1985. Ekonomi, Pariwisata, Sejarah dan Prosesnya. Kanisius: Yogyakarta.

123. Styorini, K. dan Mayang Hapsari. 2011. Wajib Budaya Sebagai Ketahanan Sosial Budaya: Studi Kasus Bahasa Indonesia. Prociding The 4th International Conference on Indonesian Studies: "Unity, Diversity, and Future".

124. Subadra, I Nengah. 2006. Ekowisata Hutan Mangrove Dalam Pembangunan Pariwisata Berkelanjutan: Studi Kasus di Mangrove Information Center, Desa Pemogan, Kecamatan Denpasar Selatan, Kota Denpasar. Tesis. Universitas Udayana: Denpasar.

125. Sugiharto, Eko. 2007. Tingkat Kesejahteraan Masyarakat Nelayan Desa Benua Baru Ilir Berdasarkan Indikator Badan Pusat Statistik. EPP. Vol 4 No 2, 2007.

126. Sukanto, 1983. Beberapa Upaya untuk Meningkatkan Partisipasi Masyarakat dalam Pembangunan. Analisa. Yogyakarta.

127. Sumampouw, M. 2004. "Perencanaan Darat-Laut yang Terintegrasi dengan Menggunakan Informasi Spasial yang Partisipatif." Jacub Rais, et al. Menata Ruang Laut Terpadu. Jakarta: Pradnya Paramita.

128. Supriana N. 1997. Pengembangan Wisata Alam di Kawasan Pelestarian Alam. Planning Sustainable Tourism. ITB. Bandung.

129. Sutamihardja. 2004. Perubahan Lingkungan Global; Program Stusi Pengelolaan Sumber Daya Alam dan Lingkungan: IPB: Bogor.

130. Suwena, I Ketut. 2010. Format Pariwisata Masa Depan; dalam Pariwisata Berkelanjutan Dalam Pusaran Krisis Global. Udayana University Press: Denpasar.

131. Syahriar \& Darwanto. 2015. Modal Sosial Dalam Pengembangan Ekonomi Pariwisata (Kasus Daerah Objek Wisata Colo Kabupaten Kudus). Dikses tanggal 2 Maret 2018.

132. Taroepratjeka, Harsono. 1998. Ilmu Pengetahuan dan Teknologi Dalam Pengembangan Sumber Daya Manusia di Bidang Pariwisata. Prosiding. Lokakarya Pendidikan Kepariwisataan Menyongsong Era Globalisasi, Kerjasama Pusdiklat Depparsenibud, Hildiktipari, P2Par-ITB: Bandung.

133. Taylor, Peter. 2006. Who Are The Capacity Builders?, Community Development Foundation.

134. Theron, F., 2005. Public Participation as a Micro-level Development Strategy. In I. Davids, F. Theron \& K.J. Maphunye, eds. Participatory Development in South Africa: A 
Development Management Perspective. Pretoria: J. L. van Schaik Publishers.

135. Timothy, D.J., 1999. Participatory Planning: a View of tourism in Indonesia.Annals of Tourism Research, 26, pp.371-91.

136. Todaro, Michael P. 2000. Pembangunan Ekonomi di Dunia Ketiga. Buku 2. Edisi Ketujuh. Jakarta: Penerbit Erlangga.

137. 2006. Pembangunan Ekonomi di Dunia Ketiga. Penerbit Erlangga: Jakarta.

138. Tosun, C \& Timothy, D.J 2003. Appropriate planning for tourism in destination communities: Participation, incremental growth and collaboration. In S. Singh, D.J. Timothy \& R.K. Dowling (Eds.), Tourism in destination communities (pp. 181-204). Wallingford: CAB International

139. 2003. Community Participation in the Tourism Development Process. Journal of Tourism Studies, 14(2), pp.1-15.

140. Tosun, C., 1999. Towards a Typology of Community Participation in the Tourism Development Process. Anatolia: An International Journal of Tourism and Hospitality Research, 10(2), pp.113-34.

141. 2000. Limits to community participation in the tourism development process in developing countries. Tourism Management, 21, pp.613-33.

142. Trejos, B. dan L.N. Chiang. 2009. Local Economic Linkages to Community Based Tourism in Rural Costa Rica. Singapore Journal of Tropical Geography 30.

143. Triambodo, S., \& Damanik, J. (2015). Analisis Strategi Penguatan Kelembagaan Desa Wisata Berbasis Ekonomi Kreatif (Studi di Desa Wisata Kerajinan Tenun Dusun Gamplong, Desa Sumberrahayu, Kecamatan Moyudan, Kabupaten Sleman, DIY). Universitas Gadjah Mada, Yogyakarta.

144. Utami, N.W.A. 2011. Aspek Kelembagaan dan Partisipasi Masyarakat Dalam Pengelolaan Kawasan Wisata Senggigi, Nusa Tenggara Barat. Tesis.

145. UNWTO dn UNEP. 2005.Making Tourism More Sustainable: A Guide for Policy Makers. Madrid, Spain: UNWTO, Madrid and UNEP, Paris

146. UNWTO. 2009. Definition of Tourist dan Tourism. Retrived online [accessed on 21st March, 2012] from: http://www.wordtourismorganisation.com.

147. Voydanoff, Patricia. 2001. Conceptualizing community in the context of work and family. Community, Work and Family 4 (2): 133-156.

148. Warner, Karen dan Margaret Kern. 2013. A City of Wellbeing, The what, why \& how of measuring community wellbeing, Researched, Written \& Produced for the City of Santa Monica Office of Wellbeing.

149. Wojowarsito, 1976. Kamus Umum Lengkap: Inggris - Indonesia, Indonesia - Inggris. Penerbit Hasta. Bandung.

150. 2001. Challenges of sustainable tourism development in the developing world: the case of Turkey. Tourism Management, 22, pp.289-303.

151. 2002. Host Perception of Impacts: A Comparative Tourism Study. Annals of Tourism, 29(1), pp.231-53.

152. 2006. Expected nature of community participation in tourism development. Tourism Management, 27(3), pp.493-504.

153. Woolcock, M. 1998. Social Capital and Economic Development: Toward o Theoretical Synthesis and Policy Framework. Theory and Society, 27 (2): 151-208.

154. Wowor, Alexander Johannes. 2011. Pariwisata Bagi Masyarakat Lokal. Disertasi. Program Pascasarjana UKSW: Salatiga.

155. Yaman, A.R. \& Mohd, A., 2004. Community-based Ecotourism: A New Proposition for Sustainable Development and Environmental Conservation in Malaysia. Journal of Applied Science, 4(4), pp.583-89.

156. Yuliarmi, Ni Nyoman. 2011. Peranan Modal Sosial Dalam Pemberdayaan Industri Karajinan di Provinsi Bali, Denpasar, Fakultas Ekonomi Universitas Udayana.

157. Yustika, Ahmad Erani. 2008. Ekonomi Kelembagaan, Definisi, Teori dan Strategi. Banyumedia Publishing, Malang.

158. Zhao, W. \& Ritchie, J.R.B., 2007. Tourism and Poverty Alleviation: An Integrative Research Framework. Current Issues in Tourism, 10, pp.119-43. 